\title{
Geologic Map of the Suquamish 7.5' Quadrangle and Part of the Seattle North 7.5' x 15' Quadrangle, Kitsap County, Washington
}

By Ralph A. Haugerud and Kathy Goetz Troost

Pamphlet to accompany

Scientific Investigations Map 3181 
This page intentionally left blank 


\section{Contents}

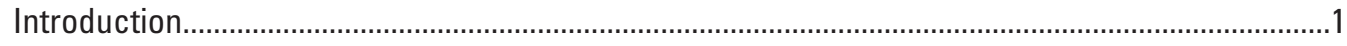

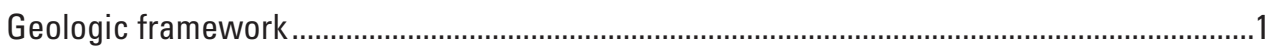

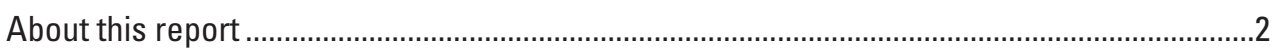

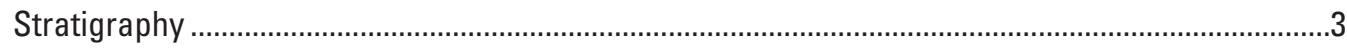

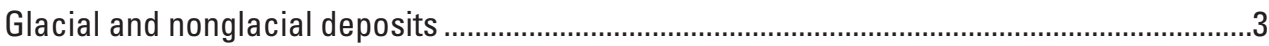

Deposits older than Olympia interglaciation of Armstrong and others (1965)..................3

Deposits older than Vashon stade of Fraser glaciation of Armstrong and

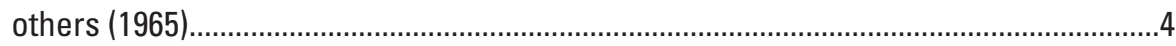

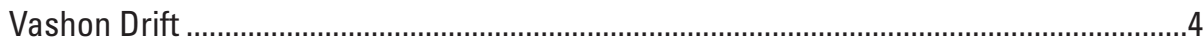

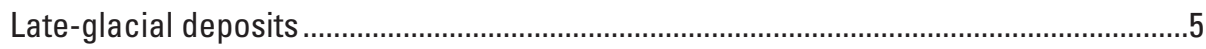

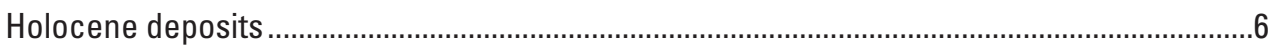

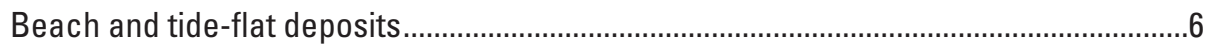

Landslide deposits ..................................................................................................

Wetland deposits and alluvium ...................................................................................

Modified land and fill................................................................................................

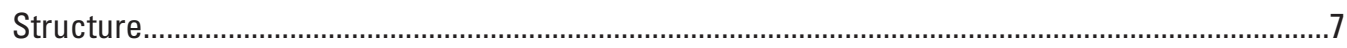

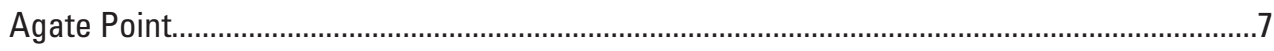

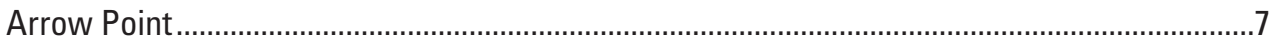

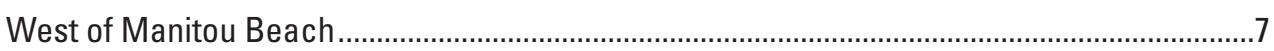

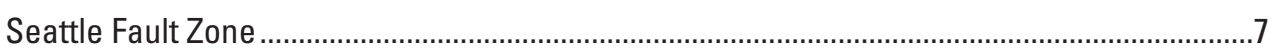

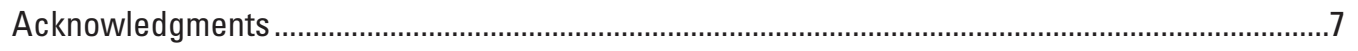

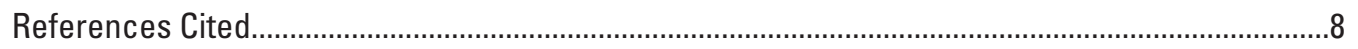

Tables

1. ${ }^{14} \mathrm{C}$ ages from the beds of University Point (Qup) ……....................................................... 
This page intentionally left blank 


\section{Introduction}

The Suquamish 7.5' quadrangle is in the center of the Puget Lowland, Washington. The quadrangle contains the northern two-thirds of Bainbridge Island and adjacent parts of the Kitsap Peninsula. Puget Sound and contiguous waterways form 35 percent of the map area. Maximum elevation is $137 \mathrm{~m}$ in the northwest corner of the quadrangle, west of Suquamish; the modal elevation is $44 \mathrm{~m}$. The center of the quadrangle is $20 \mathrm{~km}$ west-northwest of downtown Seattle. Winslow, in the southeast corner of the quadrangle, is a 35-minute ferry ride from Seattle.

At Bremerton, $10 \mathrm{~km}$ southwest of Winslow, the mean annual precipitation for the period 1971-2000 was $137 \mathrm{~cm}$ (54 in). The average January daily low temperature was $1.5^{\circ} \mathrm{C}$ $\left(35^{\circ} \mathrm{F}\right)$; mean August daily high was $24^{\circ} \mathrm{C}\left(76^{\circ} \mathrm{F}\right)$. The temperate climate encourages dense vegetation. Second- and thirdgrowth forest covers most of the land. Common tree species are Douglas fir (Pseudotsuga menziesii), western hemlock (Tsuga heterophylla), western red cedar (Thuja plicata), bigleaf maple (Acer macrophylla), and alder (Alnus rubra). Undergrowth is lush: the cross-country pedestrian especially notices dense salmonberry (Rubus spectabilis), sword fern (Polystichum andersonii), salal (Gaultheria shallon), and, locally, exotic English ivy (Hedera helix). Open areas, unless grazed or mowed, are commonly filled with two exotic species of blackberry (Rubus discolor and R. laciniatus) or scrub alder.

Earliest known inhabitants of the area were coast dwellers of the Suquampsh (or Suquamish) tribe, who depended on shellfish and salmon for a large part of their diet. In the 18th and early 19th centuries, their numbers were much diminished by Euro-American diseases. About half of the present-day members of the Suquamish Tribe live on the Port Madison reservation at the north edge of the quadrangle. European exploration of Puget Sound commenced in 1792, when the British ships, Discovery and Chatham, under the command of George Vancouver, anchored off the southeast corner of Bainbridge Island while the party explored the inland waterways. Vancouver named Puget Sound (originally, just that part of the sound south of The Narrows at Tacoma) and Port Orchard for members of his party. In 1841, the U.S. Exploring Expedition, under the command of Charles Wilkes, spent two months mapping Puget Sound. Bainbridge Island, Point Jefferson, Port Madison, and Point Monroe are among the features they named. Wilkes named Agate Passage for the expedition's artist.

Subsequent Euro-American settlement was greatly encouraged by the California gold rush (1849), the growth of San Francisco, and consequent demand for lumber produced by tidewater sawmills, including one at Port Madison. Truck gardening, especially of strawberries, was extensive on Bainbridge Island until the Second World War, when many of the farmers were interned because of their Japanese ancestry. In 2000, the quadrangle was home to about 30,000 people, many of whom commute by ferry, automobile, and bus to jobs in Seattle and Bremerton.

Sceva (1957), Garling and others (1965), and Deeter (1979) have produced geologic maps of all or part of Suquamish quadrangle. Yount and Gower (1991) and Yount and others
(1993) compiled and, in part, reinterpreted these maps at $1: 100,000$ scale.

This study was undertaken in response to (1) awareness of the hazard posed by future earthquakes in the Seattle Fault Zone, at the south edge of the quadrangle, and the need to marshal geologic evidence for the rate and style of deformation; (2) increasing population on Bainbridge Island and consequent pressure on groundwater resources; (3) concern about landslide hazards; and (4) awareness of the role that the nearshore zone plays in supporting marine resources.

\section{Geologic framework}

The Suquamish quadrangle lies within the Salish Lowland physiographic province (Haugerud, 2004), a broad region in the forearc of the Cascade Volcanic Arc that extends from south of Olympia, Washington, to north of Campbell River, British Columbia, and includes both the Puget Lowland of western Washington and the Georgia Depression of northwestern Washington and southwestern British Columbia. To the east are the Cascade Range and Coast Mountains; to the west is the outer-arc high of the Coast Ranges. The Salish Lowland is the locus of late Cenozoic subsidence: Jones (1996) indicates as much as $1 \mathrm{~km}$ of unconsolidated fill beneath some areas. The Lowland is crossed by east-west topographic highs formed by bedrock uplifts. A northern San Juan high divides the Lowland into Georgia Depression and Puget Lowland subprovinces. A southern high, which lies athwart the south end of Bainbridge Island immediately south of the map area, coincides with the Seattle Fault Zone along which uplift has brought Eocene rocks to elevations of $800-1,200 \mathrm{~m}, 8-10 \mathrm{~km}$ higher than equivalent strata in the floor of the Seattle structural basin that underlies central and northern Bainbridge Island and areas to the east (Brocher and others, 2001; Blakely and others, 2002). Deformation along the Seattle Fault appears to be driven by north-south shortening of the Cascade forearc (Wells and others, 1998).

Where Tertiary strata are exposed in uplifts of the Seattle Fault Zone, early to middle Eocene, largely submarine basalt (Crescent Formation) is overlain by thick late-middle and late Eocene fluvial to deltaic sandstone with intercalated andesitic volcanic rock (Puget Group), overlain by latest Eocene-Oligocene (Fulmer, 1975) continental shelf to nearshore tuffaceous marine strata of the Blakeley Formation. Locally, fluvial conglomerate, sandstone, siltstone, and peat of the mid-Miocene (Sherrod and others, 2002) Blakely Harbor Formation crop out. Ten Brink and others (2002; see also Brocher and others, 2004) infer that onset of deposition of the Blakely Harbor Formation corresponds to the beginning of offset on the Seattle Fault.

Pleistocene glacial deposits that underlie most of the Puget Lowland have been studied for over a century (fig. 1). The stratigraphy of the most recent glaciation is fairly well known. Older glaciations, interglacial periods, and the resulting stratigraphy are much less understood. Booth and others (2004) provide a useful summary and references. Willis (1898), 
after examining landforms and deposits in the Tacoma area, named two north-derived glacial drift sequences: a younger Vashon Drift and an older Admiralty Drift. Crandell and others (1958) recognized and named four glaciations in the southeastern Puget Lowland. From youngest to oldest, these were Vashon Glaciation, Olympia Interglaciation, Salmon Springs Glaciation, Puyallup Interglaciation, Stuck Glaciation, Alderton Interglaciation, and Orting Glaciation. Only the deposits of the Vashon Drift and the preceding Olympia Interglaciation are young enough (younger than about $40,000{ }^{14} \mathrm{C}$ yr B.P.) to be dated by radiocarbon means. On Whidbey Island, $\sim 80 \mathrm{~km}$ north of the Tacoma area studied by Willis and by Crandell and others, Easterbrook and others (1967) observed two drift layers beneath the Vashon Drift. They named these older drifts the Possession Drift and Double Bluff Drift, separated by nonglacial deposits of the Whidbey Formation.

As noted by most workers, Pleistocene deposits of different ages in the central Puget Lowland are compositionally similar. Observable distinctions are between north-derived (rich in volcanic, granitoid, and metamorphic rocks), eastderived (richer in volcanic debris derived from the Cascade Arc, especially hypersthene of probable Mount Rainier origin), and west-derived (rich in basalt and graywacke from the Olympic Mountains) deposits and between glacial (rapidly deposited, little or no organic material, diamict present) and nonglacial (slowly deposited, peat-bearing) deposits. With limited outcrop, even these distinctions cannot always be made, and most recent studies, including this one, have resorted to widespread lumping of pre-Vashon strata.

Armstrong and others (1965) noted that regionally the Vashon Drift is associated with three episodes of Late Pleistocene ice growth - their Evans Creek, Vashon, and Sumas stadesthat constitute their Fraser Glaciation. The base of their Fraser Glaciation is strongly time-transgressive. In the central Puget Lowland, the Fraser Glaciation is represented only by deposits of the Vashon stade. Thus, the names "Fraser" and "Vashon" have been used almost synonymously, but outside of the central Puget Lowland Fraser explicitly includes events and deposits older (Evans Creek stade, $\sim 24,000{ }^{14} \mathrm{C}$ yr B.P.) and younger (Sumas stade, $\sim 11,000{ }^{14} \mathrm{C}$ yr B.P.) than deposits of the Vashon stade, which in the central Puget Lowland were deposited between $\sim 14,550$ and $\sim 13,600{ }^{14} \mathrm{C}$ yr B.P. (Porter and Swanson, 1998).

Immediately east of Bainbridge Island, at Fort Lawton in Seattle, Mullineaux and others (1965) formally subdivided the lower part of the Vashon Drift. They named the Lawton Clay Member (lacustrine silt and clay, commonly with varvelike layering, little or no organic debris) and the Esperance Sand Member (massive and plane-bedded sand, overlain by cross-bedded sand, locally with foreset bedding, silt and gravel, and coarsening upwards; commonly overlain by till). Their Esperance Sand Member was restricted from an earlier proposal by Newcomb (1952) that included silts and clays as a basal member.

Figure 1 compares Pleistocene stratigraphies used on earlier geologic maps of Bainbridge Island with the stratigraphy used on recent geologic maps of areas in the central Puget Lowland and the stratigraphy used in this report.

\section{About this report}

Haugerud (2009) mapped almost all postglacial deposits and ice-contact deposits from detailed lidar topography collected in 1996-97 and 2000 on behalf of the Puget Sound Lidar Consortium (Harding and Berghoff, 2000; Haugerud and others, 2003). Haugerud, Evan Thoms, and Brett Cox walked almost all of the quadrangle's shoreline, traversed many stream gullies, and inspected road cuts and construction sites to observe deposit character and collect structural data.

Mapping the extent of Vashon-age till is challenging. Throughout the central Puget Lowland, the uppermost meter of unlithified deposits is marked by extensive bioturbation, minor addition of eolian material, clayey alteration, and variable oxidation. Many road- and stream-cuts in this low-relief landscape are confined to this weathered zone. Even where the underlying material is fine grained, the top meter is commonly pebbly. The genesis of such deposits is unclear: in some places the pebbles may be derived from up-slope exposures of pebbly deposits, but it is likely that, upon deglaciation, much of the landscape was littered with a thin skim of englacial and supraglacial debris that lacked the associated fine-grained material, compaction, and thickness necessary to make a mappable till. The tendency of Vashon-age till to reflect the composition of subglacial materials that lie within a few kilometers in the ice-source direction compounds the difficulty: a sandy, brown subsoil with abundant small pebbles may be derived from underlying brown sand and gravel or may be derived from a till derived from such a deposit. Earlier workers appear to have dealt with these difficulties by assuming that glacially shaped uplands of the area are mantled with till, unless good outcrops demonstrated otherwise. Along much of the shoreline, bluff exposures of older deposits that extend into the topmost, strongly weathered meter demonstrate that this is incorrect.

To delineate the extent of Vashon-age till, we supplemented outcrops in shoreline bluffs, stream banks, road cuts, ditches, and foundation excavations by digging or augering numerous shallow $(0.5-1.5 \mathrm{~m})$ holes. We extracted subsurface data from the database compiled by Troost and colleagues (GeoMapNW, 2007), focusing on observations of the uppermost $10 \mathrm{ft}(3 \mathrm{~m})$ that included an interpreted stratigraphic unit (for example, "Vashon till", "advance outwash") or a distinctive lithology (for example, "till"). Field identification of till in shallow exposures and identification of till from subsurface data are both prone to error; in the many places where interpretations from the subsurface database conflicted with our field observations, we gave precedence to field observations. Because of such uncertainties, contacts between till and older units in upland areas are shown as scratch boundaries (position very uncertain).

Cross sections were interpreted by Troost from borehole logs in the GeoMapNW (2007) subsurface database and subsequently revised on the basis of additional map data. In general, data from boreholes within 2,200 $\mathrm{ft}(670 \mathrm{~m})$ of the section line were considered when interpreting sections. Borehole collar elevations were obtained by intersecting the reported map location with the lidar elevation model. Borehole logs shown on the 
cross sections depict the material class assigned by compilers of the GeoMapNW (2007) database.

One of the consequences of mapping on an accurate lidar base is that neither this topography nor the interpreted geology matches available base maps. We thus present this geologic map on a sparse custom base showing contours calculated from the lidar elevation model, Public Land Survey System land lines, some roads and road names, and some place names, but without streams or municipal boundaries.

This report supercedes and expands upon U.S. Geological Survey Open-File Report 2005-1387 (Haugerud, 2005).

\section{Stratigraphy}

\section{Glacial and nonglacial deposits}

\section{Deposits older than Olympia interglaciation of Armstrong and others (1965)}

Similar physical characteristics of deposits of different ages and limited outcrops make correlation of Quaternary deposits older than the Vashon Drift uncertain. On this map, we have not subdivided these older deposits, except where distinctive physical characteristics or structural position suggest correlation from outcrop to outcrop.

Sediment of Rockaway Beach.-A massive, fine-grained unit is interpreted to occur in the subsurface at the south end of cross section $E-E^{\prime}$. Texture and position suggest correlation with a distinctive assemblage of disrupted, gray, waxy silt, clay, and fine sand that crops out about $2 \mathrm{~km}$ south of the quadrangle on Rockaway Beach, where it overlies the Miocene Blakely Harbor Formation (Haugerud, 2005). Disruption of the beds suggests slumping shortly after the beds were deposited on a subaqueous slope. The facies suggests ice-proximal deposition, which explains the weak inference of a Quaternary age. Because the unit is older than Vashon Drift and is probably glacial, it is likely older than Olympia Interglaciation.
Beds of University Point.-Well-sorted dark gravel and associated sand, silt, and peat crop out in several locales. Gravel beds are typically no more than 1-2 m thick and most pebbles are greywacke or basalt, suggesting derivation from the Olympic Mountains to the west. Pebbles are rarely larger than $6 \mathrm{~cm}$ in diameter. Gravel beds commonly display good imbrication. Good outcrops show that strata are commonly organized into repeated 2- to 3-m-thick, fining-upward sequences that indicate relatively slow fluvial deposition of channel gravels overlain by sands and succeeded by overbank silt and peat. Bluffs of this unit have a pinkish to orange-brown hue when seen from a distance. Some beds are lithified: strata at some outcrops are best described as mudstone, sandstone, and conglomerate. These deposits may have formed during several nonglacial intervals, but their similar character and relative proximity encouraged us to map these beds as one lithostratigraphic unit. Presence of granitoid pebbles and lack of clayey alteration distinguish these beds from similar depositional facies in the Blakely Harbor Formation of the Bremerton East quadrangle directly south of the map area. Outcrops at University Point, on the shore of Port Orchard west of Fletcher Bay, are particularly good. Beds of University Point, $25 \mathrm{~m}$ thick, crop out in the bluff north of Fletcher Bay. Poor outcrop suggests as much as $65 \mathrm{~m}$ of section may be present on the south side of Fletcher Bay. Interpretation of subsurface data indicates a maximum thickness as great as $160 \mathrm{~m}$ (cross section $\left.D-D^{\prime}\right)$.

Deeter (1979, p. 47-58) recognized the similarity of gravel and interbedded sand, silt, and peat at University Point at a gravel pit on Miller Road on Bainbridge Island, at a gravel pit near Hwy 305 in sec. 4, T. 25 N., R. 2 E., at Fletcher Bay, and north of Rolling Bay (all of which we map as beds of University Point. He noted the high concentration of dark graywacke clasts and the scarcity of granitoid clasts and reports that Crandell (in Levin and others, 1965) inferred an Olympic Mountains origin for the gravels. Nonetheless, Deeter interpreted these strata as glacial sediments and tentatively assigned them to the Possession Drift of Easterbrook and others (1967) on the basis of infinite radiocarbon ages (W-1459, UW-449; table 1) and his "difficulties in explaining alpine glaciers advancing from the

Table $1 .{ }^{14} \mathrm{C}$ ages from the beds of University Point (Qup)

\begin{tabular}{|l|l|l|l|l|}
\hline \multicolumn{1}{|c|}{ Sample ID } & \multicolumn{1}{|c|}{ Location (lat, long) } & $\begin{array}{c}\text { Material } \\
\text { analyzed }\end{array}$ & \multicolumn{1}{|c|}{ Age $\left({ }^{\mathbf{1 4} C \text { yr B.P.) }}\right.$} & \multicolumn{1}{|c|}{ Reference } \\
\hline USGS-555 & $47^{\circ} 40.3^{\prime}, 122^{\circ} 32.7^{\prime}$ & Peat & $>48,000$ & S. W. Robinson in Yount and others, 1993 \\
\hline USGS-556 & $47^{\circ} 40.3^{\prime}, 122^{\circ} 32.7^{\prime}$ & Wood & $40,000 \pm 2,100$ & S.W. Robinson in Yount and others, 1993 \\
\hline USGS-557 & $47^{\circ} 40.3^{\prime}, 122^{\circ} 32.7^{\prime}$ & Peat & $45,500 \pm 2,800$ & S.W. Robinson in Yount and others, 1993 \\
\hline UW-447 & $47^{\circ} 44.8^{\prime}, 122^{\circ} 31.2^{\prime}{ }^{1}$ & Wood & $>40,000$ & Deeter, 1979 \\
\hline UW-449 & $47^{\circ} 40.3^{\prime}, 122^{\circ} 32.8^{\prime}{ }^{1}$ & Peat & $>40,000$ & Deeter, 1979 \\
\hline W-1459 & $47^{\circ} 38.4^{\prime}, 122^{\circ} 35.5^{\prime}{ }^{1}$ & Peat & $>38,000$ & Levin and others, 1965 \\
\hline
\end{tabular}

${ }^{1}$ Latitude and longitude as reported by Yount and others (1993). Locations on map and in database are as figured by Deeter (1979) 
Olympic Mountains across Hood Canal during an interglaciation and also because the nature of coarse gravel deposits in the lowland on an interglacial floodplain is difficult to explain especially when present day streams do not carry anything as coarse as these deposits" (Deeter, 1979, p. 55-56). These supposed difficulties are unconvincing: the beds were deposited by slowly aggrading streams as evidenced by their good organization and common peat, they are not dominated by north-derived debris, modern streams do carry pebbles as large as $6 \mathrm{~cm}$, and Hood Canal may not have existed during an earlier interglacial period.

Near Ferncliff, along the shoreline north of Rolling Bay, and between Fletcher and Manzanita Bays, beds of University Point appear to stratigraphically underlie pre-Olympia glacial deposits, though direct superposition was not observed. This implies that the beds of University Point are at least as old as the Whidbey Formation. Infinite and near-infinite radiocarbon ages (table 1) are consistent with this interpretation.

Pre-Olympia glacial deposits. - Pre-Vashon, and thus pre-Olympia, glacial deposits (unit Qpog) crop out at several locales. Isolated outcrops of till and bedded silt occur northeast of Lemolo in the streambed in the center of sec. 19, T. $26 \mathrm{~N}$., R. 2 E., where they underlie thick, extensive sand of pre-Vashon till age. Till crops out beneath pre-Vashon deposits on the beach between Battle and Arrow Points (SW $1 \frac{1}{4}$ sec. 8, T. 25 N., R. 2 E.). Folded and locally faulted diamict, gravel, and thickbedded sand crop out in the shoreline bluffs east of Agate Point (NE $1 / 4$ Sec. 28, T. 26 N., R. 2 E.). Deformed massive silt with pebbles - probable dropstones - crops out at the base of the bluff along Rolling Bay. Deeter (1979, p. 27) reported snail, clam, and barnacle fossils in these outcrops; these may be evidence for glaciomarine deposition. Till crops out along the bluff east of Ferncliff, where it underlies Lawton Clay. Along the north shore of Port Madison, till and gravel are exposed at the base of the bluff $1 \mathrm{~km}$ east of Indianola (sec. 14, T. $26 \mathrm{~N}$., R. 2 E.). Deeter (1979, p. 21-24) described these outcrops and reported an infinite radiocarbon age (table 1, sample UW-447).

The stratigraphy preserved in landslide debris in the beach on the east shore of Port Orchard (sec. 29, T. 25 N., R. 2 E.) suggests two pre-Vashon-age glaciations. The debris contains oxidized gravel above pebbly till above discontinuous peat above silt and clay that contains dropstones.

Other pre-Olympia age deposits.-Older depoits in the sub,surface are assigned to stratigraphic units Qpog, Qpog , Qpog $_{\mathrm{c}}$, Qpog, Qpog, Qpog $_{\mathrm{c}}$, Qpfo, and $\mathrm{Qpo}_{c}$ on the basis of inferred depositional facies and predominant grain size: glacial, glacial marine, and nonglacial, coarse and fine.

\section{Deposits older than Vashon stade of Fraser glaciation of Armstrong and others (1965)}

Most of the area mapped as undifferentiated pre-Vashonage deposits (unit Qpv) appears to be underlain by probable fluvial and lacustrine fine quartzofeldspathic sand, pebbly sand, and gravel with lesser peat and silt, of probable fluvial and lacustrine origin. This unit is largely equivalent to coarsegrained, pre-Fraser-age deposits mapped on recent maps of nearby areas (for example, unit Qpf in Booth and Waldron, 2004). It is likely that unit Qpv locally includes sand, silt, and clay of early Vashon age as well as beds that, with better outcrop, could be assigned to units Qup, Qpog, Qpor, and Qpv . Some of the deposits mapped as unit Qpv are lithified and are best described as sandstone and conglomerate.

Silt and clay with associated peat crop out southeast of Agate Point and are mapped as fine-grained pre-Vashon-age deposits (unit $Q p v_{f}$ ). Except for the occurrence of peat, these beds resemble the Lawton Clay (unit Qvlc); they could have been deposited during Olympia interglaciation.

Beds of mud, clay, and silt - locally with dropstonesexposed in the bluffs and beach at and southwest of Arrow Point are overlain by fine sand. Together, the fine-grained beds and sand beds are similar to the Lawton Clay and Esperance Sand of the Vashon Drift. However, these beds are probably older than Vashon Drift, because they appear to lie beneath an older till that crops out on the beach farther southwest.

\section{Vashon Drift}

The Vashon stade Cordilleran ice sheet gathered in the mountains of British Columbia and flowed south, reaching its maximum southern extent near Olympia at about 16,900 cal. yr B.P.; it covered Bainbridge Island for about 1,000 years, from 17,600 to 16,600 cal. yr B.P. (Porter and Swanson, 1998), where it reached a thickness of about $1 \mathrm{~km}$ (Thorson, 1980).

The geomorphic effects of the ice sheet are impressive. Meltwater issuing from the advancing ice deposited clay, silt, sand, and gravel of the Lawton Clay and the Esperance Sand, as described below. The net effect was to fill low spots throughout the Lowland and produce a broad, south-sloping alluvial plain (Crandell and others, 1965; Booth, 1994). This surface is preserved, with modification, as an upland surface that is the dominant landform of the Puget Lowland. At the latitude of Bainbridge Island, this surface is at an elevation of about 140 $\mathrm{m}$. The overriding glacier then eroded, shaped, and smoothed its outwash plain. The broad, anastomosing, sinuous troughs filled by Puget Sound, Port Orchard, Port Madison, and Rich Passage were eroded beneath the glacier (Crandell and others, 1965; Booth, 1994), as demonstrated by widespread blanketing by lodgment till, pervasive smoothing by south-directed flow, and the inability of postglacial streams to erode hollows that extend far beneath any postglacial base level. Booth (1994) suggested that erosion of the troughs was primarily by flowing subglacial water. The glacier also formed pervasive north-south flutes (elongate drumlins) that had heights of tens of meters, widths of hundreds of meters, and lengths of several kilometers. Parallel orientation and lack of sinuousity indicate that the flutes were directly shaped by moving ice.

Within the map area, the Vashon Drift comprises proglacial sediments of the Lawton Clay and Esperance Sand Members, subglacial lodgment till (Vashon till), and younger ice-contact deposits.

Lawton Clay Member.-Once Vashon-age ice reached the northeast corner of the Olympic Peninsula, near Port Townsend, it dammed the Puget Lowland and turned low-elevation parts 
of the Lowland into one or more large lakes that had an outlet at Black Lake, south of Olympia (Mullineaux and others, 1965; Waitt and Thorson, 1983; Booth and others, 2004). The Lawton Clay Member of the Vashon Drift was deposited in this (these) lake(s). Clay and silt were transported by suspension in glacial meltwater that fed the lake. Minor coarser debris was probably ice-rafted. Lawton sedimentation at any particular locale ended when Vashon-age ice approached close enough that the supplied sediment was dominantly sand. The present elevation of the Black Lake outlet is about $42 \mathrm{~m}$ (Thorson, 1989; Bretz, 1913). Allowing for some Vashon-age incision of the outlet and isostatic depression by the advancing ice sheet, the likely level of this lake surface in the map area is somewhat higher than $42 \mathrm{~m}$. Excluding tectonism, Lawton Clay should not be present at elevations greater than the lake level, and it should be very thin at near-lake-level elevations. Fittingly, most recognized Lawton Clay occurs near modern sea level.

Gray to blue-gray, thinly (centimeters) to thickly (tens of centimeters) bedded silt, clay, and fine sand, locally with dropstones and lenses of sand and gravel, are mapped as the Lawton Clay Member of the Vashon Drift, where evidence indicates that such beds are part of a continuous coarsening-upwards succession that culminated in Vashon-age till. This evidence comprises (1) a gradational contact with overlying, uncemented, fine to medium sand and (2) the occurrence of laterally extensive landslide complexes at its base that suggest the silt and clay beds and overlying sand deposits are equally extensive. Silt and clay of the Lawton Clay are common as landslide debris embedded in the modern beach. The highest exposure of Lawton Clay in the map area is at about $45 \mathrm{~m}$ elevation.

Esperance Sand Member.-We map thick, commonly homogeneous, fine to medium sand that is usually poorly consolidated and locally pebbly and, in places, coarsens upwards as the Esperance Sand Member of the Vashon Drift. Recently published maps of the central Puget Lowland (for example, Booth and Waldron, 2004; Troost and others, 2005) have mapped equivalent strata as "Vashon advance outwash deposits (Qva)". We have revived the nomenclature of Mullineaux and others (1965) to emphasize that (1) in the Suquamish quadrangle, this unit is predominantly sandy and lacks the associated gravel layers found elsewhere within the Booth and Waldron (2004) and Troost and others (2005) unit Qva and (2) we have mapped a lithostratigraphic unit with its attendant uncertainties, rather than a time-process unit.

Good exposures of Esperance Sand are present in abandoned borrow pits along SR 305 east of Lemolo. Previous workers mapped these sandy deposits as recessional outwash, but high-resolution topographic data show that the land surface was shaped by overriding ice and has been modified little since glaciation. There is no sign of the constructional surface of a recessional outwash deposit. Esperance Sand fills a paleovalley that extended northwest-southeast along the present-day low between Fletcher Bay and Eagle Harbor. Similarly, Esperance Sand near Agate Passage appears to be buttressed against older deposits (unit Qpv) to the east. These beds are advance outwash, deposited in front of the advancing Vashon-age glacier. At lower elevations, much of the unit is massive to plane-bedded and probably was deposited by mass sediment gravity flows avalanching off advancing delta faces. At higher elevations, some of this unit is strongly crossbedded and clearly fluvial.

In coastal bluffs, the Esperance Sand is prone to landsliding, thus exposures are commonly ephemeral. In early 2004 there was an excellent, accessible exposure of Esperance Sand and overlying Vashon-age till in the NE $1 / 4$ sec. 12, T. 25 N., R. 1 E. Subsoil developed on Esperance Sand is loose sand.

Our present understanding of Vashon-age glaciation (for example, Booth, 1994) requires that, at the latitude of Bainbridge Island, advance outwash deposits at lower elevations (below $42+\mathrm{m}$, at elevations below the inferred surface of the proglacial lake) cannot be fluvial; therefore, we infer that subaerial fluvial deposits beneath Vashon till at lower elevations must be older than the Vashon Drift.

Till. - The Vashon-age glacier covered much of the Puget Lowland with a thin layer of lodgment till. In the Suquamish quadrangle, this till varies from less than $1 \mathrm{~m}$ (which is unmappable) to more than $35 \mathrm{~m}$ thick. Locally, till appears to be thicker on south-facing (down-ice flow) slopes than on northfacing slopes. Till is mostly compact diamict that is rich in sand and well-rounded pebbles. Most pebbles are less than $10 \mathrm{~cm}$ in diameter. Only rarely are clasts larger or angular. Meltwater streams carried the majority of the sediment moved (albeit indirectly) by the glacier and deposited it as outwash. Most debris in the till was reworked from overriden outwash; only a minor amount was carried within, or on top of, the ice sheet. Lenses of sorted, layered material (silt, sand, gravel) are common in the till, attesting to the near-pervasive presence of flowing water beneath the Vashon-age ice sheet. Good outcrops of Vashonage till are common in shoreline bluffs. Particularly accessible and instructive are outcrops on the west side of Agate Passage, west of Point Jefferson, south of Battle Point, and north of Brownsville. Wave-etched outcrops commonly show foliation that is less evident in upland outcrops. Presumably, foliation records simple shear induced by traction from the overlying ice. Minor folds in the till, where evident, commonly have northsouth axes: the rotation of folds into the transport direction indicates large shear strain. Rare clastic dikes thread some outcrops.

Crossbedded coarse gravel near sea level southwest of Point Jefferson is mapped as a gravel facies (unit Qvt $t_{g}$ ) of the Vashon-age till, because it appears continuous with the overlying till (thus may not be much older) and the gravel elevation is too low to have been deposited by a subaerial stream in front of the advancing Vashon-age glacier. This gravel may have been deposited by one of the subglacial streams posited by Booth (1994).

Ice-contact deposits. - North of Winslow, near Manitou Beach, and northwest of Point Bolin, surface morphology suggests that buried ice fragments melted and the adjacent deposits collapsed. These areas are mapped as ice-contact deposits.

\section{Late-glacial deposits}

The weight of the Vashon-age ice sheet induced significant isostatic subsidence at the time of glaciation. As the ice sheet retreated, it dammed extensive ice-marginal lakes in 
the Puget Lowland (Bretz, 1913). As the mass of the waning ice sheet decreased, isostatic uplift lagged, as recorded by now-elevated shorelines and marine deposits. Thorson (1989) further described and analyzed these features and interpreted postglacial rebound with an up-to-the-north gradient of about $1 \mathrm{~m} / \mathrm{km}$. Most rebound occurred within a few thousand years of deglaciation (Thorson, 1989; Dethier and others, 1995; Clague and James, 2002). At the latitude of the Suquamish quadrangle, Thorson's analysis suggests present-day elevations of lateglacial lake surfaces of about $110 \mathrm{~m}$ (glacial Lake Russell) and $50 \mathrm{~m}$ (glacial Lake Bretz) and a post-ice marine limit at a present-day elevation of 20 to $30 \mathrm{~m}$. High-resolution topography locally shows shorelines developed along the late-glacial lakes, but any corresponding shoreline deposits must have been no thicker than a meter or so and are indistinguishable from other weathered and bioturbated deposits of sand and gravel.

In contrast, deposits related to late-glacial marine inundation and subsequent emergence are locally preserved. On the north side of Fletcher Bay, shoreline bluff exposures show 1 to $2 \mathrm{~m}$ of sorted sand, gravel, and silt, which are mapped as emergence gravels (unit Qeg). Elsewhere, the presence of similar deposits is inferred from subtle smoothing of the glacial land surface. These deposits are probably former beach sands and gravels, though they may include some nearshore stream deposits. Emergence gravels were not deposited by streams flowing from melting Vashon-age ice, because Bainbridge Island appears to have been ice-free earlier, at the time of glacial Lake Bretz, when shoreline knicks were developed on the north part of the island near Seabold (secs. 28 and 33, T. 26 N., R. 2 E.) and south of the community of Port Madison (secs. 2 and 3, T. 25 N., R. 2 E.). By the time Lake Bretz drained and Puget Sound returned to marine conditions, the ice margin was almost certainly at least $20 \mathrm{~km}$ farther north — no closer than the north tip of the Kitsap Peninsula.

That mappable marine shoreline deposits are present, whereas late-glacial lake shoreline deposits are not, could reflect longer inundation at lower elevations - the areas submerged by salt water after the ice melted were earlier submerged by ice-marginal lakes and the rate of isostatic rebound slowed with time. We think it is more likely that marine tides kept a significant vertical extent of the shoreline free of armoring vegetation and subject to wave action and more extensive reworking of underlying deposits.

\section{Holocene deposits}

\section{Beach and tide-flat deposits}

Mapping beach deposits along Puget Sound presents an unresolved set of problems. First and foremost is lack of an adequate base map. At present, medium- and high-resolution topography for most of the Puget Lowland extends down only to the high-water line. Second, many Puget Sound beaches are underlain by pebble to cobble gravel. We do not have an efficient technique to routinely ascertain whether this sediment is a thin veneer over a beach platform eroded into older material or a thicker deposit of recently accreted material. For this study, surface materials are mapped landward of the break in slope at the high-water line, either the crest of the beach berm or the toe of the bluff. Thus, the only beach deposits mapped (unit $\mathrm{Qb}$ ) are the sand, gravel, and logs of accreted back-beach platforms and the associated silt, muck, and peat deposited in lagoons occluded behind beach berms and spits. Deposits farther seaward are mapped only where older material is visible through the veneer of modern beach sediment.

On a geologic time scale, it is clear that the beaches and their associated deposits are ephemeral. A good example is visible at the south side of Skiff Point, where soft, likely Holocene peat that was probably deposited in a marsh behind a beach berm is exposed in the upper intertidal zone in front of the present berm, suggesting that the berm has migrated landward and (or) to the north. Extensive bulkheads along the shoreline demonstrate that many property owners are concerned that the beaches are ephemeral on a human time scale. Certainly the bulkheads are ephemeral, because they are commonly deformed by landslides, the fill behind bulkheads is sapped by wave action, or, ironically, new beach is accreted in front of a bulkhead.

The large spits at Point Monroe and at the mouth of Miller Bay have been extensively modified for residential construction and are mapped as modified land.

\section{Landslide deposits}

Coastal landslides are particularly abundant where Esperance Sand overlies Lawton Clay along a contact at or above the mean-high-water line. The correlation is so strong that, with moderate accuracy, one could infer the distribution of Esperance Sand and Lawton Clay on the basis of extensive coastal landslides. Landsliding is episodic. Regionally, extensive failures occurred following heavy rainfall on saturated soils in early 1972 and early 1997. Tubbs (1974) is an excellent reference on landsliding in this region.

Changes in details of bluff morphology between collection of lidar data in 1997 and 2000 and final field work in 2003-2004 reinforce the conclusion that landsliding is an ongoing process. Evidence for ongoing movement includes subangular clasts of fragile bedded silt and clay in the beach at the toe of the large slide at Yeomalt (sec. 23, T. 25 N., R. 2 E.). However, some coastal bluffs, particularly those cut entirely in the beds of University Point, appear to be relatively stable.

We used high-resolution topographic data to map large deep-seated landslide deposits. Because the lidar data do not image shallow debris flows, commonly no more than $1 \mathrm{~m}$ thick, that are the most common and frequent slope failures, we did not map the deposits of these events. Nor did we map colluvial debris that mantles many hillslopes.

\section{Wetland deposits and alluvium}

The rolling glaciated upland of the Puget Lowland, which contains numerous closed depressions commonly underlain by low-permeability Vashon-age till or older silt and clay, has numerous upland wetlands. Other wetlands are coastal, 
occluded behind beach berms and spits. In places, streams have aggraded across such lows and deposited mappable amounts of alluvium. Less commonly, alluvial flats that are wide enough to map fringe streams incised into the upland surface.

We mapped wetland deposits (unit Qw) and alluvium (unit Qal) largely on the basis of surface morphology, supplemented by field observations and reference to the U.S. Fish and Wildlife Service's National Wetlands Inventory (http://www.fws.gov/ wetlands/).

\section{Modified land and fill}

Mostly we did not map modified land. Significant exceptions are the spit at Point Monroe, where bulkheads and fill have disguised the berm crest and probably raised the average level of the ground surface, and the extensive paved area around the shopping mall and high school north of Winslow. Mapped fill at the site of the former Port Madison sawmill includes anthropogenic peat, recognizable from fragments of dimension lumber. Because of their potential for failure during severe seismic shaking if they were not adequately compacted during construction, we mapped road fills wherever they are evident in high-resolution lidar topography.

\section{Structure}

The Quaternary deposits of the Suquamish quadrangle are significantly deformed. Because of poor exposure, it is commonly unclear whether observed deformation is tectonic or due to landsliding, ice push, or syndepositional failure of sediment deposited on a slope. We have omitted all observations of bedding that obviously has been deformed by landsliding. In a few places, bedding measurements have been reduced in number for the purposes of presentation at map scale. Measurements that are "approximate" (symbols with open centers) have significant uncertainty in the reported measurement, because of poor exposure or strong crossbedding. Measurements that are not "approximate" describe the orientation of structures to within a few degrees. Locales where probable tectonic deformation is evident are discussed below.

\section{Agate Point}

Sediments of pre-Vashon age, including some of glacial origin, that crop out on the bluff within $0.25 \mathrm{~km}$ southeast of Agate Point are folded and faulted. An unmapped small fault strikes northeast, is nearly vertical, and has an observed dip separation of less than $1 \mathrm{~m}$. Bedding attitudes define a northeast-trending fold as well.

Clay, silt, and peat that crop out in the intertidal zone farther southeast of Agate Point, beneath a landslide on the bluff, are deformed. The deformation pattern is sufficiently consistent that landslide-related deformation seems unlikely. A small northeast-trending fold is evident in outcrop. Bedding strike is parallel to the fold axis and to the axis of the fold defined by bedding farther northwest, closer to Agate Point. Several unmapped small northwest-trending faults cut the section with an aggregate left-lateral separation of $1.5 \mathrm{~m}$.

To the southwest of Agate Point at Seabold, on strike with these dipping beds, topographically higher pre-Vashon deposits are horizontal. Perhaps these higher deposits are younger and were deposited after the folding recorded on the beach southeast of Agate Point.

\section{Arrow Point}

Fine sand, silt, and clay exposed in shoreline bluffs 0.7 $\mathrm{km}$ southwest of Arrow Point are strongly folded and have dips locally in excess of $45^{\circ}$. This section shows local intrastratal deformation that is probably syndepositional; the longerwavelength folding of the entire section is probably younger. Bedding attitudes suggest folding around a northwest trend.

\section{West of Manitou Beach}

West of Manitou Beach, in the interior of the island (center of sec. 15, T. 25 N., R. 2 E.), an isolated outcrop of thin-bedded fine sand and silt evinces an east dip of $34^{\circ}$. There is no indication that this is landslide-related deformation. We did not find other outcrops nearby to verify this attitude. On the strength of this one observation, as well as the inference that beds of University Point are missing in this vicinity, cross section $C-C^{\prime}$ depicts a significant anticline in this area. We infer protracted folding, because there appears to be a significant angular unconformity at the base of a discontinuous glacial unit that underlies the beds of University Point. Farther north, subsurface data (cross section $B-B^{\prime}$ ) suggest beds of University Point are folded by the northern continuation of this anticline.

\section{Seattle Fault Zone}

The Seattle Fault Zone (Gower and others, 1985; Bucknam and others, 1992; Blakely and others, 2002) crosses Bainbridge Island, with most deformation directly south of the Suquamish quadrangle. Along the east shore of Port Orchard south of Fletcher Bay and from there west to the head of Eagle Harbor, the Esperance Sand and older strata dip to the north. The northern limit of dipping beds runs from Yeomalt to Fletcher Bay. Cross sections $D-D^{\prime}$ and $E-E^{\prime}$ depict this homocline, which appears to mark the northern limit of late Quaternary deformation associated with the Seattle Fault.

\section{Acknowledgments}

We thank Kitsap Public Utility District (KPUD) for contracting the 1996-97 lidar survey of Bainbridge Island and 
Greg Berghoff (KPUD) for bringing this survey to the attention of the geologic community. We thank our colleagues in the Puget Sound Lidar Consortium for acquiring public-domain lidar data for the remainder of the quadrangle. Without these data, this map would be very different. Brett Cox and Evan Thoms contributed geologic mapping. Scott Morse (City of Bainbridge Island) supplied useful GIS base data. Ross Hathaway (City of Bainbridge Island) provided encouragement and access to certain outcrops. Reviews by Russ Evarts, Derek Booth, and Joel Robinson led to significant improvement of this report.

\section{References Cited}

Armstrong, J.E., Crandell, D.R., Easterbrook, D.J., and Noble, J.B., 1965, Late Pleistocene stratigraphy and chronology in southwestern British Columbia and northwestern Washington: Geological Society of America Bulletin, v. 76, p. 321-330.

Blakely, R.J., Wells, R.E., Weaver, C.S., Johnson, S.Y., 2002, Location, structure, and seismicity of the Seattle Fault Zone, Washington-Evidence from aeromagnetic anomalies, geologic mapping, and seismic-reflection data: Geological Society of America Bulletin, v. 114, no. 2, p. 169-177.

Booth, D.B., 1994, Glaciofluvial infilling and scour of the Puget Lowland, Washington, during ice-sheet glaciation: Geology, v. 22, p. 695-698.

Booth, D.B., Troost, K.G., Clague, J.J., and Waitt, R.B., 2004, The Cordilleran ice sheet, in Gillespie, A.R., Porter, S.C., and Atwater, B.F., eds., The Quaternary Period in the United States: International Union for Quaternary Research, Elsevier Press, p. 17-43.

Booth, D.B., and Waldron, H.H., 2004, Geologic map of the Des Moines quadrangle, Washington: U.S. Geological Survey Scientific Investigations Map 2855, scale 1:24,000, http://pubs.usgs.gov/sim/2004/2855/.

Bretz, J H., 1913, Glaciation of the Puget Sound region: Washington Geological Survey Bulletin 8, 244 p.

Brocher, T.M., Blakely, R.J., and Wells, R.E., 2004, Interpretation of the Seattle uplift, Washington, as a passive-roof duplex: Bulletin of the Seismological Society of America, v. 94, p. 1379-1401.

Brocher, T.M., Parsons, T.E., Blakely, R.J., Christensen, N.I., Fisher, M.A., Wells, R.E. (SHIPS Working Group), 2001, Upper crustal structure in Puget Lowland, Washington-Results from the 1998 Seismic Hazards Investigations in Puget Sound: Journal of Geophysical Research, v. 106, no. B7, p. 13,541-13,564.

Bucknam, R.C., Hemphill-Haley, E., and Leopold, E.B., 1992, Abrupt uplift within the past 1,700 years at southern Puget Sound, Washington: Science, v. 258, p. 1611-1614.

Clague, J.J., and James, T.S., 2002, History and isostatic effects of the last ice sheet in southern British Columbia: Quaternary Science Reviews, v. 21. p. 71-87.
Crandell, D.R., Mullineaux, D.R., and Waldron, H.H., 1958, Pleistocene sequence in the southeastern part of the Puget Sound lowland, Washington: American Journal of Science, v. 256, p. 384-397.

Crandell, D.R., Mullineaux, D.R., and Waldron, H.H., 1965, Age and origin of the Puget Sound trough in western Washington: U.S. Geological Survey Professional Paper 525-B, p. B132-B136.

Deeter, J.D., 1979, Quaternary geology and stratigraphy of Kitsap County, Bellingham, Western Washington University, M.S. thesis, 175 p., map scale $\sim 1: 48,000$.

Dethier, D.P., Pessl, F., Keuler, R.F., Balzarini, M.A., and Pevear, D.R., 1995, Late Wisconsinan glaciomarine deposition and isostatic rebound, northern Puget Lowland, Washington: Geological Society of America Bulletin, v. 107, p. 1288-1303.

Easterbrook, D.J., Crandell, D.R., and Leopold, E.B., 1967, Pre-Olympia Pleistocene stratigraphy and chronology in the central Puget Lowland, Washington: Geological Society of America Bulletin, v. 78, p. 13-20.

Fulmer, C.V., 1975, Stratigraphy and paleontology of the type Blakeley and Blakely Harbor formations, in Weaver, D.W., Hornaday, G.R., and Tipton, A., eds., Paleogene symposium and selected technical papers - Conference on future energy horizons of the Pacific Coast: American Association of Petroleum Geologists, Pacific Section, p. 210-271.

Garling, M.E., Molenaar, D., Van Denburgh, A.S., and Fiedler, G.H., 1965, Water resources and geology of the Kitsap Peninsula and certain adjacent islands: Washington Division of Water Resources, Water Supply Bulletin 18, 309 p., scale 1:62,500.

GeoMapNW, 2007, GeomapNW data deliverable-October 2007 [database on CD-ROM]: University of Washington, Pacific Northwest Center for Geologic Mapping Studies. (Also available at http://geomapnw.ess.washington.edu/.)

Gower, H.D., Yount, J.C., and Crosson, R.S.. 1985, Seismotectonic map of the Puget Sound region, Washington: U.S. Geological Survey Miscellaneous Investigations Series I-1613, $15 \mathrm{p}$.

Harding, D.J., and Berghoff, G.S., 2000, Fault scarp detection beneath dense vegetation cover-Airborne lidar mapping of the Seattle Fault Zone, Bainbridge Island, Washington State: Proceedings of the American Society of Photogrammetry and Remote Sensing Annual Conference, Washington, D.C., May, 2000, 9 p. (Also available at http://puget soundlidar.org/harding.pdf.)

Haugerud, R.A., 2004, Cascadia-Physiography: U.S. Geological Survey Geologic Investigations Series I-2689, scale $1: 2,000,000$.

Haugerud, R.A., 2005, Preliminary geologic map of Bainbridge Island, Washington: U.S. Geological Survey Open-File Report 2005-1387, scale 1:24,000, at http://pubs.usgs.gov/ of $/ 2005 / 1387 /$.

Haugerud, R.A., 2009, Preliminary geomorphic map of the Kitsap Peninsula, Washington: U.S. Geological Survey Open-File Report 2009-1033, scale 1:36,000, at http:// pubs.usgs.gov/of/2009/1033/. 
Haugerud, R.A., Harding, D.J., Johnson, S.Y., Harless, J.L., Weaver, C.S., and Sherrod, B.L., 2003, High-resolution topography of the Puget Lowland, Washington-A bonanza for earth science: GSA Today, v. 13, no. 6, p. 4-10.

Jones, M.A., 1996, Thickness of unconsolidated deposits in the Puget Sound Lowland, Washington and British Columbia: U.S. Geological Survey Water-Resources Investigations Report 94-4133, map scale 1:455,000.

Levin, B., Ives, P.C., Oman, C.L., and Rubin, M., 1965, U.S. Geological Survey radiocarbon dates VII: Radiocarbon, v. 7, p. 372-398.

Mullineaux, D.R., Waldron, H.H., and Rubin, M., 1965, Stratigraphy and chronology of late interglacial and early Vashon glacial time in the Seattle area, Washington: U.S. Geological Survey Bulletin 1194-O, p. O1-O10.

Newcomb, R.C., 1952, Ground-water resources of Snohomish County, Washington: U.S. Geological Survey Water-Supply Paper 1135, 133 p.

Porter, S.C., and Swanson, T.W., 1998, Radiocarbon age constraints on rates of advance and retreat of the Puget lobe of the Cordilleran ice sheet during the last glaciation: Quaternary Research, v. 50, p. 205-213.

Sceva, J.E., 1957, Geology and ground-water resources of Kitsap County, Washington: U.S. Geological Survey Water-Supply Paper 1413, 178 p., scale 1:48,000.

Sherrod, B.L., Vance, J.A., and Leopold, E., 2002, Fission track ages of Tertiary bedrock in the hanging wall of the Seattle Fault Zone: Geological Society of America Abstracts with Programs, v. 34, no. 5, p. 108.

ten Brink, U.S., Molzer, P.C., Fisher, M.A., Blakely, R.J., Bucknam, R.C., Parsons, T., Crosson, R.S., and Creager, K.S., 2002, Subsurface geometry and evolution of the Seattle Fault Zone and the Seattle basin, Washington:
Bulletin of the Seismological Society of America, v. 92, p. 1737-1753.

Thorson, R.M., 1980, Ice sheet glaciation of the Puget Lowland, Washington, during the Vashon stade: Quaternary

Research, v. 13, p. 303-321.

Thorson, R.M., 1989, Glacio-isostatic response of the Puget Sound area, Washington: Geological Society of America Bulletin, v. 101, p. 1163-1174.

Troost, K.G., Booth, D.B., Wisher, A.P., and Shimel, S.A., 2005, The geologic map of Seattle-A progress report: U.S. Geological Survey Open-File Report 2005-1252, scale 1:24,000, at http://pubs.usgs.gov/ofr/2005/1252/.

Tubbs, D.W., 1974, Landslides in Seattle: Washington Division of Geology and Earth Resources, Information Circular 52, $15 \mathrm{p}$.

Waitt, R.B., Jr., and Thorson, R.M., 1983, The Cordilleran ice sheet in Washington, Idaho, and Montana, in Wright, H.E., Jr., and Porter, S.C., eds., Late-Quaternary environments of the United States, volume 1-The Late Pleistocene: Minneapolis, University of Minnesota Press, 407 p., chap. 3, p. 53-70.

Wells, R.E., Weaver, C.S., and Blakely, R.J., 1998, Fore arc migration in Cascadia and its neotectonic significance: Geology, v. 26, p. 759-762.

Willis, B., 1898, Drift phenomena of the Puget Sound: Geological Society of America Bulletin, v. 9, p. 111-162.

Yount, J.C., and Gower, H.D., 1991, Bedrock geologic map of the Seattle 30' by 60' quadrangle, Washington: U.S. Geological Survey Open-File Report 91-147, scale $1: 100,000$.

Yount, J.C., Minard, J.P., and Dembroff, G.R., 1993, Geologic map of surficial deposits in the Seattle 30' x 60' quadrangle, Washington: U.S. Geological Survey Open-file Report 93-233, 2 sheets, scale 1:100,000. 